\title{
20. PRELIMINARY ANALYSIS OF EXTRACTABLE LIPIDS IN SEDIMENTS FROM THE EASTERN NORTH ATLANTIC (LEG 108): COMPARISON OF A COASTAL UPWELLING AREA (SITE 658) WITH A NONUPWELLING AREA (SITE 659)1
}

\author{
H. L. ten Haven, ${ }^{2}$ J. Rullkötter, ${ }^{2}$ and R. Stein ${ }^{3}$
}

\begin{abstract}
Preliminary results of lipid analyses of six samples from Site 658, underlying a present-day active upwelling cell, and of one sample from Site 659 are reported in this paper. Long-chain unsaturated ketones of prymnesiophyceae algae origin are the most abundant compounds in extracts from Site 658, followed by marine-derived steroids. $n$-Alkanes are of minor importance in these samples, but they predominate in the sample from Site 659. Our interpretation of the results indicates that organic-matter preservation was good to excellent at Site 658 and poor at Site 659 , and that an analysis of only aliphatic hydrocarbons leads to an overestimation of the contribution of terrigenous organic matter at Site 658. Increased primary productivity, high sedimentation rates, and oxygendepleted water masses associated with upwelling are thought to be the key factors for preservation. At the present stage of research, no specific biomarkers have been found that indicate upwelling.
\end{abstract}

\section{INTRODUCTION}

One of the objectives of Leg 108 was to study the history of the coastal upwelling system off northwest Africa (Leg 108 Shipboard Scientific Party, 1986). To this end, two sites were drilled at the northwest African continental margin. Site 658 $\left(20^{\prime} 44.95^{\prime} \mathrm{N}, 18^{\prime} 34.85^{\prime} \mathrm{W}\right.$, with a water depth of $\left.2263 \mathrm{~m}\right)$ is located on the continental slope west of Cap Blanc, directly underneath a major coastal upwelling cell. For comparison, drilling was performed at Site $659\left(18^{\prime} 04.63^{\prime} \mathrm{N}, 21^{\prime} 01.57^{\prime} \mathrm{W}\right.$, with a water depth of $3070 \mathrm{~m}$ ), which is located northeast of the Cape Verde Islands and outside the present-day upwelling zone (Fig. 1).

Upwelling is the most important mechanism for nutrient supply to the surface-water masses off northwest Africa, resulting in an increased oceanic productivity of organic matter. In addition to upwelling, fluvial nutrient supply may have been important during times of more humid climatic conditions in northwest Africa (cf. Stein et al., this volume; Tiedemann et al., this volume). Thus, investigations of the quality and quantity of the organic matter preserved in the deep-sea sediments may yield important information about changes in paleoenvironments, such as changes in upwelling intensity and/or changes in river discharge (e.g., Stein et al., 1986; ten Haven et al., 1987b).

At present, there are no valid molecular indicators (biomarkers) for direct assessment of the presence or the intensity of coastal upwelling. Some biomarkers can be related to a contribution of diatoms when this type of organism is predominately present in the sediment, which is often the case in areas of high productivity. Examples of such compounds are 24-methyl-cholesta-5,22-dien-3 $\beta$-ol (Volkman, 1986) and loliolide (ten Haven et al., 1987c); the latter is presumably a degradation product of carotenoids with a 5,6 epoxide (Klok et al., 1984; Repeta and Gagosian, 1987). However, an assign-

\footnotetext{
${ }^{1}$ Ruddiman, W., Sarnthein, M., et al., 1989. Proc. ODP, Sci. Results, 108: College Station, TX (Ocean Drilling Program).

2 Institut für Erdöl und Organische Geochemie, KFA Jülich, Postfach 1913, D-5170 Jülich, Federal Republic of Germany.

${ }^{3}$ Institut für Geowissenschaften und Lithosphärenforschung, Universităt Giessen, Senckenbergstrasse 3, D-6300 Giessen, Federal Republic of Germany.
}

ment of these organic compounds to a definite source can only be made when micropaleontological data are available.

Bulk characteristics of the organic matter (i.e., total organic carbon, hydrogen index values, $\mathrm{C} / \mathrm{N}$ ratios), supported by kerogen microscopy, have been carried out on a large set of samples, and the results are presented by Stein et al. (this volume). This study reports the preliminary results of an investigation of the extractable lipids from a selected set of samples, using gas chromatographic and gas chromatographic/mass spectrometric (GC/MS) methods.

\section{EXPERIMENTAL METHODS}

We investigated seven samples in this study: six from Site 658 and one from Site 659 (Table 1). The sediments were thawed, dried $\left(50^{\circ} \mathrm{C}\right)$, and analyzed for their organic-carbon and carbonate contents and for the amount of hydrocarbons released during temperature-controlled pyrolysis (presented as the hydrogen index). Aliquots of sediment samples were used for organic petrography (see Stein et al., this volume).

Solvent extraction (dichloromethane, $1 \%$ methanol) was carried out by a modified flow-blending technique (Radke et al., 1978), followed by the addition of a known amount of internal standard (squalane). Subsequently, the extract was divided in two equal portions, except for the extract of the sample from Site 659. One part was separated into several compound classes by Medium Pressure Liquid Chromatography (MPLC; Radke et al., 1980). The other part was methylated with dimethylformamide-dimethylacetal (DMFDMA), chromatographed over silica with hexane/ethylacetate (3:1 $\mathrm{v} / \mathrm{v})$ to remove very polar compounds, and silylated with trimethylsilyltrifluoracetamide (MSTFA).

Gas chromatography was carried out on a Varian 3700 gas chromatograph equipped with a Gerstel programmed-temperature injector system and a fused silica capillary column $(1=50 \mathrm{~m}$, inner diameter $=0.22 \mathrm{~mm}$ ) coated with SE 54. Helium was used as a carrier gas, and the temperature was programmed from $120^{\circ} \mathrm{C}$ to $320^{\circ} \mathrm{C}$ at $3^{\circ} \mathrm{C} / \mathrm{min}$. We performed the CG/MS studies with a Carlo Erba Fractovap 4160 gas chromatograph, equipped with a fused silica capillary column $(1=50 \mathrm{~m}$; inner diameter $=0.32 \mathrm{~mm})$ coated with Ultra 2 (SE 54 equivalent) and coupled to a VG $7070 \mathrm{E}$ mass spectrometer operating at $70 \mathrm{eV}$. Helium was used as carrier gas, and the temperature programmed from $110^{\circ} \mathrm{C}$ to $300^{\circ} \mathrm{C}$ at $3^{\circ} \mathrm{C} / \mathrm{min}$.

Compound identifications are based on comparisons of relative gas chromatography retention times and mass spectra with those reported in the literature. The distribution of organic compounds is discussed in qualitative rather than quantitative terms. 


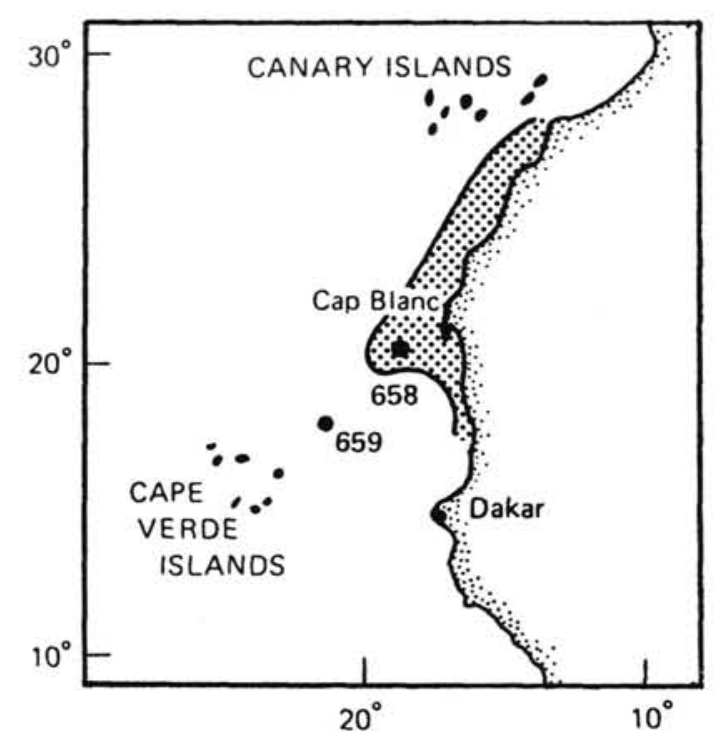

Figure 1. Location map of the northwest African continental margin indicating Sites 658 and 659 of Leg 108. The dotted area indicates the region of strong coastal upwelling during Pliocene/Pleistocene times.

\section{RESULTS AND DISCUSSION}

Depth, stratigraphic age, and bulk characteristics of the samples investigated are given in Table 1. Samples from "upwelling" Site 658, in accordance with the results of Stein et al. (this volume), are characterized by much higher total organic carbon $\left(\mathrm{C}_{\text {org }}\right)$ and hydrogen index $(\mathrm{HI})$ values than the sample from "nonupwelling" Site 659 (Fig. 1). We interpreted the elevated $\mathrm{HI}$ values as evidence for an increased contribution of marine organic matter to the sediments at Site 658 due to better preservation and higher primary productivity (cf. Stein et al., this volume). Microscopy of kerogen concentrates revealed that marine organic matter is more abundant than terrigenous organic matter in samples from Site 658 , and vice versa for the sample from Site 659 .

\section{Aliphatic Hydrocarbons}

An example of a gas chromatogram of an aliphatic hydrocarbon fraction of a sediment extract from the upwelling area (Sample 108-658B-14H-6, 130-137 cm) is given in Figure 2. The most important natural constituents are straight-chain alkanes, of which the $C_{31}$ member is predominant. The carbon preference index value $\left(\mathrm{CPI}_{24-34}\right)$ of about 4.9 confirms the immaturity of the organic matter (cf. Stein et al., this volume), as well as suggests that there is a significant contribution of terrigenous lipids to the extract (Eglinton and Hamilton, 1963).

A similar aliphatic distribution was observed in all sediment extracts from Site 658 , and only small differences in the sample from Site 659 were noted. This is in contrast to the pyrolysis and kerogen microscopy results and indicates that the aliphatic hydrocarbon fraction does not adequately represent the bulk composition of the total organic matter in these immature sediments.

Steroid and hopanoid hydrocarbons are minor compounds compared to $n$-alkanes. Relative steroid concentrations increased with depth, and in the deeper samples better mass spectra could be obtained, thus allowing the reliable identification of single components. A partially reconstructed ion chromatogram showing the steroid/hopanoid elution range in Sample 108-658A-24X-6, 88-90 cm (212.8 mbsf) is presented in Figure 3.

Triterpenoid hydrocarbons are more abundant than steroid hydrocarbons. These triterpenoids (i.e., several hopanoids and three fernene isomers, as given in Table 2), can be ascribed to a bacterial origin (e.g., Ourisson et al., 1984; Brassell et al., 1981). Another bacterial biomarker observed in all aliphatic fractions from Site 658 is 2,6,10,15,19-pentamethyleicosane (i- $\mathrm{C}_{25}$ in Fig. 2; Brassell et al., 1981). Most of the steroids are derived from nonbacterial marine organisms, with a possible uncertainty regarding the $\mathrm{C}_{29}$ steroids (Volkman, 1986).

Among the triterpenoid hydrocarbons, the distribution pattern of the fernene isomers shows significant changes with depth. Partial m/z 243 mass chromatograms of two samples are shown in Figure 4. The distribution of fernenes in the sample from 123.2 mbsf (not shown in Fig. 4) is comparable with the distribution pattern shown for the sample from 183.0 mbsf. However, in the more deeply buried sample from 212.8 mbsf, the relative abundance of the $\Delta^{8}$ and $\Delta^{\text {(11) }}$ isomers has increased (Fig. 4).

A literature survey on the distribution pattern of fernenes in marine sediments revealed that, in even more deeply buried sediments from other locations, the $\Delta^{7}$ isomer was almost absent (e.g., McEvoy et al., 1981; Brassell, 1984, 1985). Such a change in distribution pattern with depth can be ascribed to progressive isomerization to the thermodynamically more stable isomer(s) (cf. McEvoy et al., 1981; Brassell, 1985; Volkman et al., 1986).

Table 1. Background information of the samples investigated.

\begin{tabular}{|c|c|c|c|c|c|c|c|}
\hline $\begin{array}{l}\text { Core, section, } \\
\text { interval }(\mathrm{cm})\end{array}$ & $\begin{array}{l}\text { Depth } \\
\text { (mbsf) }\end{array}$ & $\begin{array}{c}\text { Lithologic } \\
\text { unit }\end{array}$ & Age & $\begin{array}{c}\mathrm{CaCO}_{3} \\
(\%)\end{array}$ & $\begin{array}{l}\mathrm{C}_{\text {org }} \\
(\%)\end{array}$ & $\frac{\mathrm{HI}}{\left(\mathrm{mg} \mathrm{HC} / \mathrm{g} \mathrm{C}_{\text {org }} \text { ) }\right.}$ & $\begin{array}{c}\text { Extract } \\
\text { yield } \\
\left.\text { (mg/g C } \mathrm{Corg}_{\text {org }}\right)\end{array}$ \\
\hline \multicolumn{8}{|l|}{ 108-658A- } \\
\hline${ }^{a} 21 X-6,7-14$ & 183.0 & II & latePliocene & 38.5 & 1.58 & 326 & 10 \\
\hline $24 X-6,88-90$ & 212.8 & II & latePliocene & n.d. & 3.22 & 375 & 9 \\
\hline \multicolumn{8}{|l|}{ 108-659B- } \\
\hline${ }^{\mathrm{a}} 2 \mathrm{H}-5,130-137$ & 9.9 & IA & Pleistocene & 41.0 & 3.06 & 308 & 6 \\
\hline a 5 - $4,130-137$ & 40.9 & IA & Pleistocene & 74.8 & 0.15 & 73 & n.d. \\
\hline${ }^{a} 5 \mathrm{H}-6,130-137$ & 37.8 & IB & Pleistocene & 46.6 & 1.42 & 365 & 13 \\
\hline $\mathrm{a}_{14 \mathrm{H}-6,130-137}$ & 123.2 & II & late Pliocene & 29.5 & 1.81 & 380 & 17 \\
\hline$a_{33 X}-3,130-137$ & 276.3 & III & early Pliocene & 6.8 & 2.23 & 378 & 25 \\
\hline
\end{tabular}

Note: $\mathrm{HI}=$ hydrogen index; n.d. = not determined.

a Samples from dedicated organic geochemistry core sections. 
Hole 658B

123.2 MBSF

ALIPHATICS

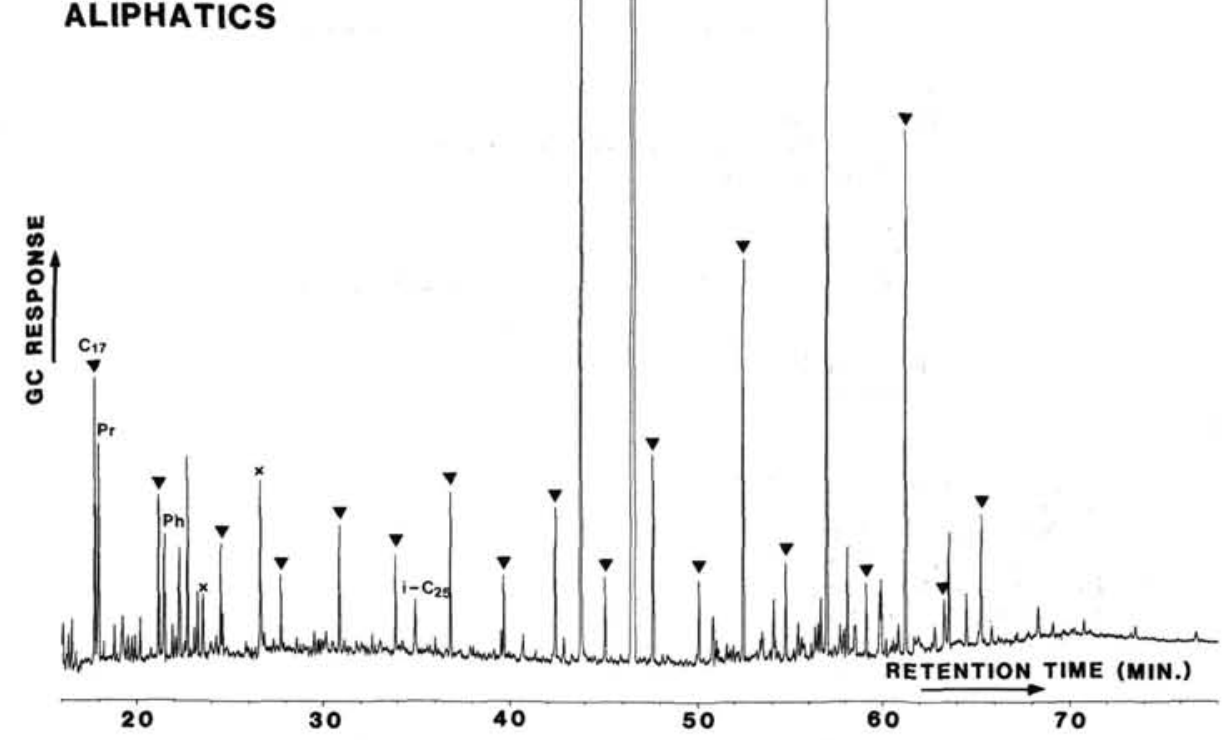

Figure 2. Gas chromatogram of the aliphatic hydrocarbon fraction of Sample 108-658B-14H-6, $130-137 \mathrm{~cm}$. $n$-Alkanes are indicated by triangles, starting at $n-\mathrm{C}_{17}$ and reaching up to $n-\mathrm{C}_{35}$. $\mathrm{Pr}=$ pristane, $\mathrm{Ph}=$ phytane, $i-\mathrm{C}_{25}=2,6,10,15,19$-pentamethyleicosane, $\mathrm{Sq}=$ squalane (internal standard), $x=$ phthalate esters (contaminants).

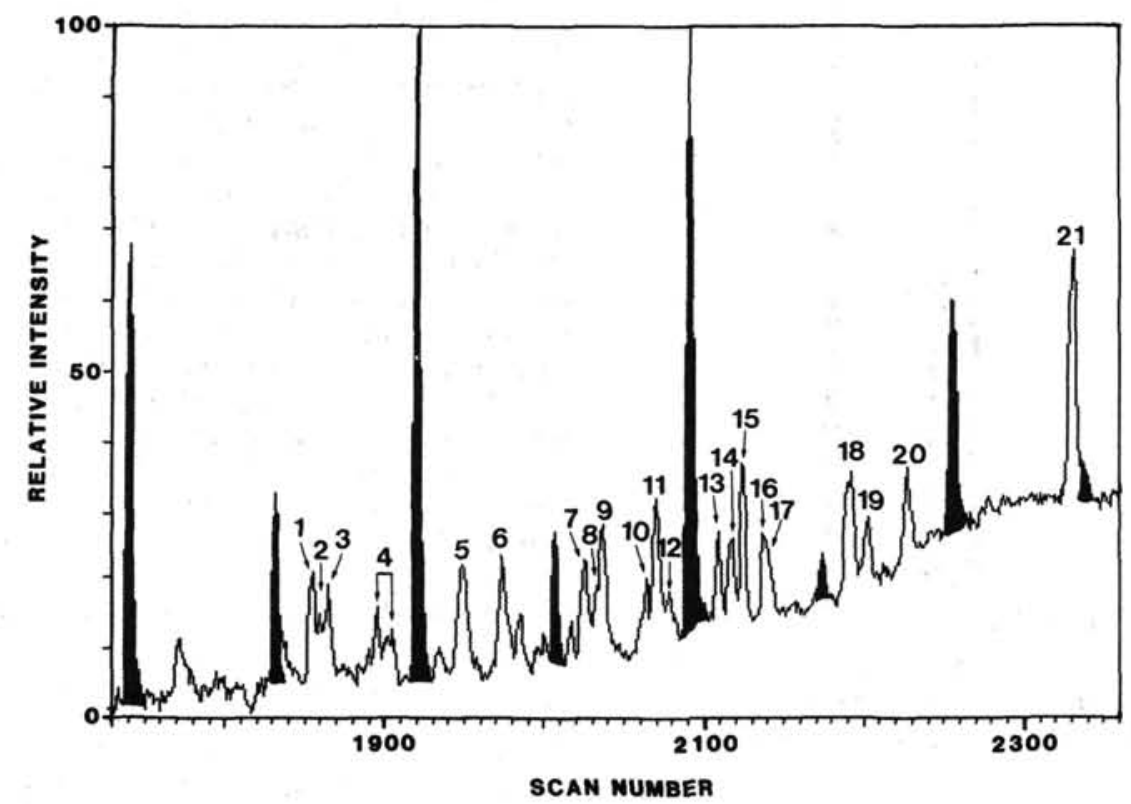

Figure 3. Partially reconstructed ion chromatogram of the aliphatic hydrocarbon fraction of Sample 108-658A-24X-6, 88-90 cm. n-Alkanes are shown in black, the first eluting one being $n-\mathrm{C}_{27}$, the last one, $n-\mathrm{C}_{34}$. Identification of all the numbered compounds is given in Table 2.

\section{Total Lipids}

Gas chromatograms of the derivatized "total lipid" extracts of five samples from Site 658 in the coastal upwelling area are shown in Figures 5A-E. The gas chromatogram of the sample from Site 659 (nonupwelling) is shown in Figure 5F. Some of the major compounds (e.g., nos. 7 and 14 in Table 3) can hardly be ascribed to any biogenic origin and are, therefore, considered to be contaminants.

If we disregard these compounds, we find that the series of long-chain unsaturated methyl and ethylketones (nos. 19 and 20 in Table 3) are the most abundant free lipid components in the sediments from Site 658, while they are of equal importance as the $n$-alkanes in the sample from Site 659. The 
Table 2. Compounds identified by gas chromatography/mass spectrometry in the aliphatic hydrocarbon fraction of Sample 108-658A-24X-6, 88-90 cm (Fig. 3).

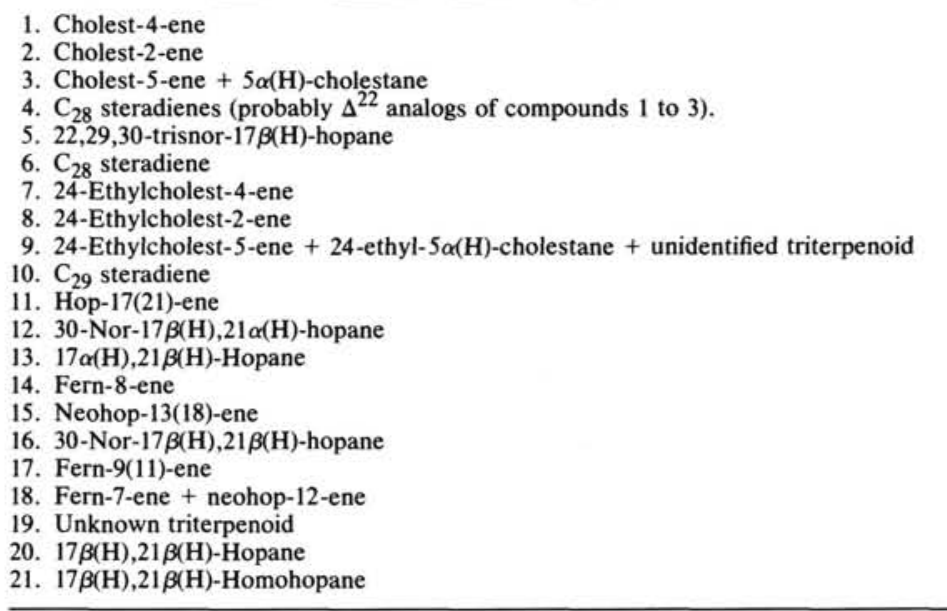

\subsection{MBSF}

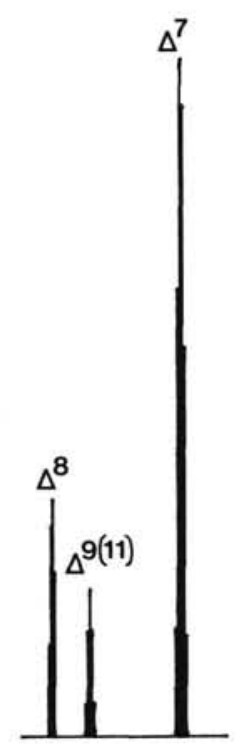

\subsection{MBSF}

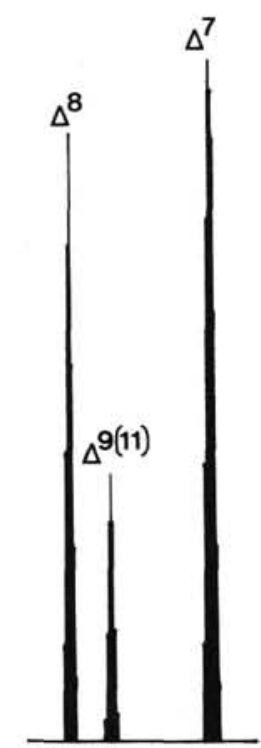

$\mathrm{m} / \mathrm{z} 243$

Figure 4. Partial mass chromatogram of $\mathrm{m} / \mathrm{z} 243$ showing the distribution of fernenes in Samples 108-658A-21X-6, 7-14 cm (183.0 mbsf) on the left and 108-658A-24X-6, 88-90 cm (212.8 mbsf) on the right.

long-chain ketones are frequently seen as very abundant compounds in "total lipid" extracts of marine sediments (cf. ten Haven et al., 1987a) and can be ascribed to an origin from prymnesiophyceae algae (Volkman et al., 1980; Marlowe et al., 1984; Brassell et al., 1986).

Other important classes of compounds at Site 658 (Figs. 5A-E) are steroids, fatty acids (e.g., nos. 15 and 17), and $n$-alkanols (e.g., nos. 16 and 18). These compound classes are of minor importance in the sediment from Site 659 (Fig. 5F). The long-chain $n$-alkanols and $n$-fatty acids are usually interpreted to be indicative of a terrigenous contribution to the organic matter (Simoneit, 1978a).

It should be mentioned here that the straight-chain fatty acids have been measured as trimethylsilyl (TMS) ethers rather than

as methyl esters. This only became clear after GC/MS measurements, where it was observed that typical fragment ions of methylated fatty acids (m/z 74 and 87 ) were shifted to m/z 117 and 132. Obviously, esterification of the fatty acids with DMFDMA did not proceed to completion, whereas no problem with hopanoid acids seems to have occurred.

We cannot rule out the possibility, therefore, that some of the unesterified fatty acids were lost during liquid chromatography on the silica column, and thus the relative concentration of these compounds may be too low in Figure 5. Also, the relative retention times of the fatty acids are affected.

The steroid distribution is complex, but with the aid of mass chromatography of specific ion fragments (e.g., $\mathrm{m} / \mathrm{z} 129$ for $\Delta^{5}$ unsaturated sterols), a considerable number of steroids could be identified (Fig. 6, Table 4). The steroids that were identified range in carbon skeletons from $\mathrm{C}_{26}$ to $\mathrm{C}_{30}$ with various levels of unsaturation, and with and without alkylation at C-4. Such a complex distribution is typical for a contribution from a wide variety of marine organisms.

Given the present state of knowledge, only the 4-methyl sterols can be ascribed to a specific origin, that is, from dinoflagellates (e.g., Boon et al., 1979; de Leeuw et al., 1983; Robinson et al., 1984). Some of the major peaks (Fig. 6) show mass spectra that at present could not be interpreted or related to specific structures.

The bacterially derived hopanoids, of which $17 \beta-(\mathrm{H})$, $21 \beta(\mathrm{H})$-bishomohopanoic acid is the most abundant compound, are present in much lower concentrations than the steroids. All the samples from "upwelling" Site 658 show a high abundance of steroids with subordinate amounts of hopanoids (Figs. 5A-E). This is in direct contrast to the sample from "nonupwelling"' Site 659 (Fig. 5F), where the $n$-alkanes dominate the "total lipid" extract. In this sample, steroids were found at low levels and hopanoids were virtually absent.

$n$-Alkan-2-ones have been positively identified only in the two deepest buried samples from Site 658 , while the isoprenoid ketone, 6,10,14-trimethylpentadecan-2-one (no. 3 in Fig. 5), is present in all samples from Site 658. The latter compound is thought to be an oxidation product of phytol originally derived from chlorophyll (Ikan et al., 1973). The former ketones are usually explained as being formed by microbiological oxidation of $n$-alkanes or by $\beta$-oxidation, 
Hole 658B

9.9 MBSF

"TOTAL LIPIDS"

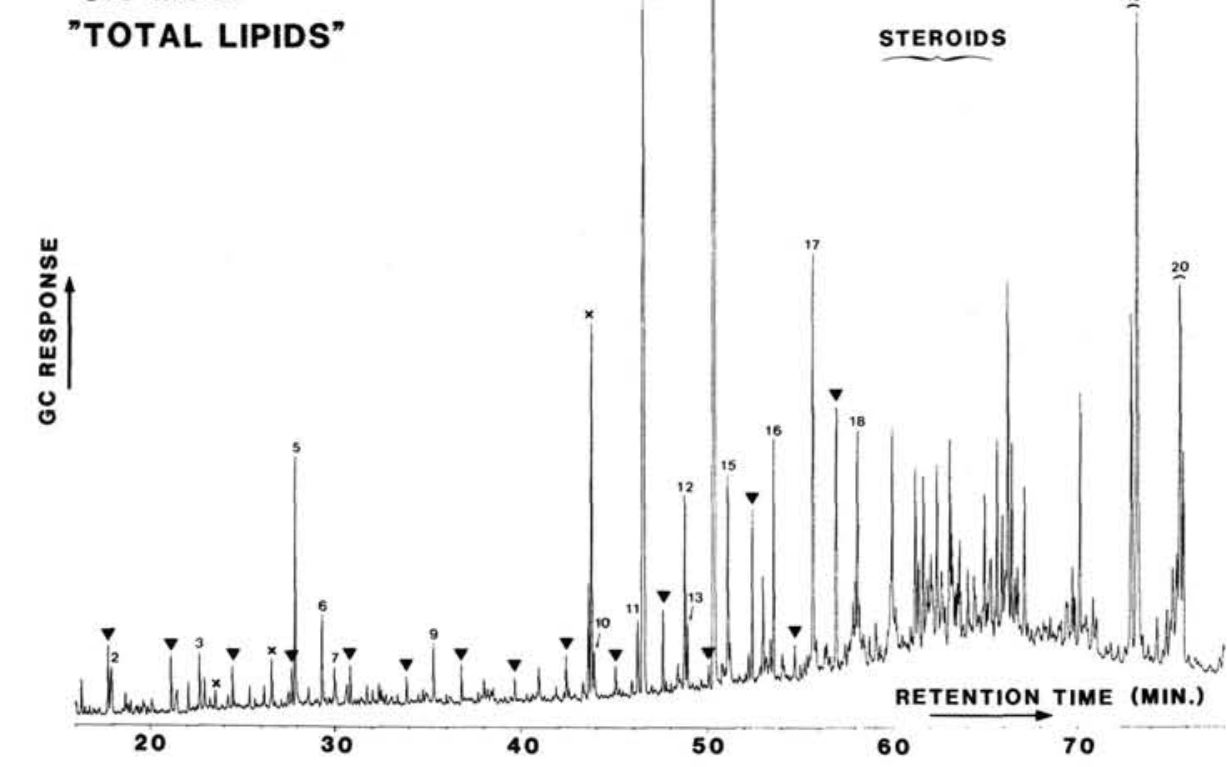

Hole 658B 37.8 MBSF "TOTAL LIPIDS"

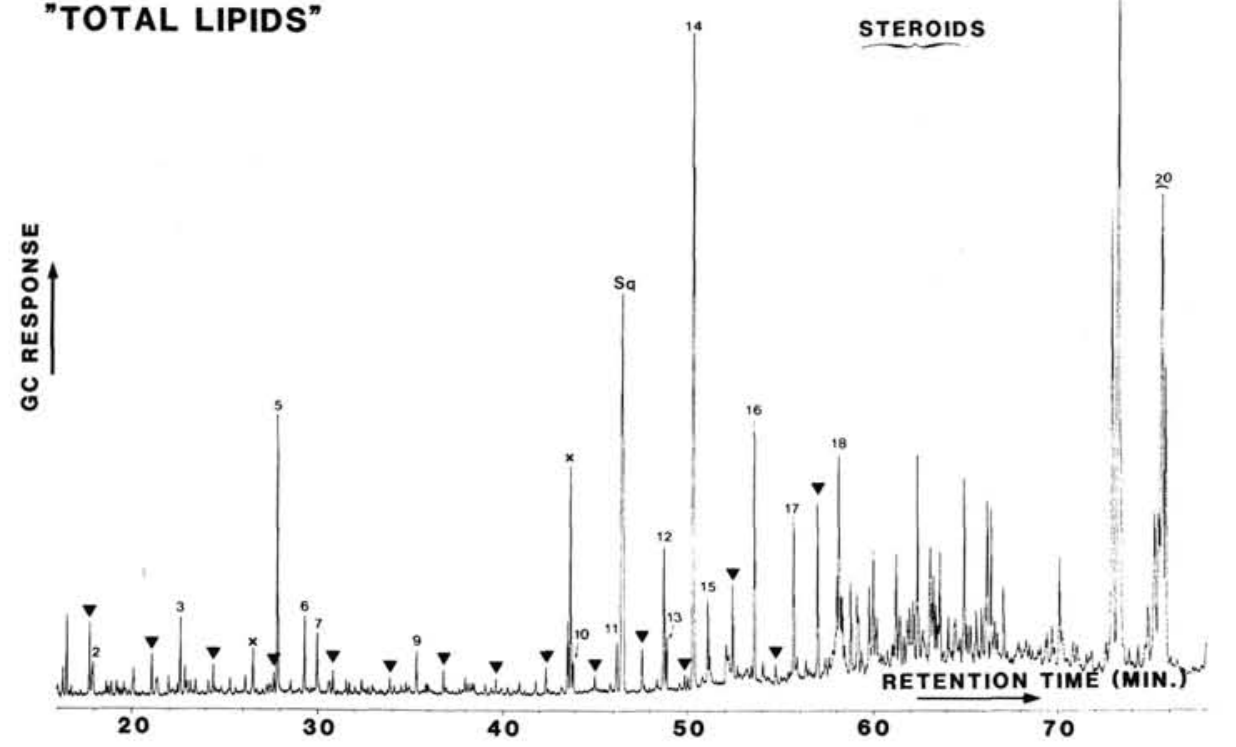

Figure 5. Gas chromatograms of "total lipid" fractions extracted from Site 658 (A-E) and Site 659 sediments (F). $n$-Alkanes are indicated by triangles, starting at $n-\mathrm{C}_{17}$ and reaching up to $n$ - $\mathrm{C}_{31}$. Identification of the numbered compounds is given in Table $3 . \mathrm{Sq}=$ squalane (internal standard), $\mathrm{x}$ $=$ phthalate esters (contaminants).

followed by decarboxylation of $n$-fatty acids (Morrison, 1969).

If one of these two mechanisms were true, one would expect to find a distribution pattern of $n$-alkan-2-ones that would more or less mimic the patterns of $n$-alkanes and/or $n$-fatty acids. Such a similarity has been observed in some cases in marine sediments (e.g., Simoneit, 1978b; Brassell et al., 1980) as well as in lake sediments (Cranwell, 1977). The distribution pattern here, exemplified by the $\mathrm{m} / \mathrm{z} 58$ mass chromatogram in Figure 7, is completely different, however. It shows a remarkable resemblance to the short-chain fatty acids and/or $\beta$-hydroxy fatty acids (cf. ten Haven et al., 1987 a) with the respective loss of one carbon atom. It seems possible that iso and anteiso $\mathrm{C}_{14}$ and $\mathrm{C}_{16}$ alkan-2-ones are also present (see doublets eluting before the $n-\mathrm{C}_{14}$ and $n-\mathrm{C}_{16}$ ketones in Fig. 7) as well as iso $\mathrm{C}_{15}$ and $\mathrm{C}_{17}$ alkan-2-ones (see single peaks eluting before $n$ - $\mathrm{C}_{15}$ and $n$ - $\mathrm{C}_{17}$ ketones in Fig. 7). An origin from $\beta$-hydroxy fatty acids, via oxidation of the alcohol moiety, and subsequent decarboxylation seems to be the most plausible explanation for the distribution of the ketones because higher homologs $\left(>C_{24}\right)$ are virtually absent. 
Hole 658B

123.2 MBSF

"TOTAL LIPIDS"

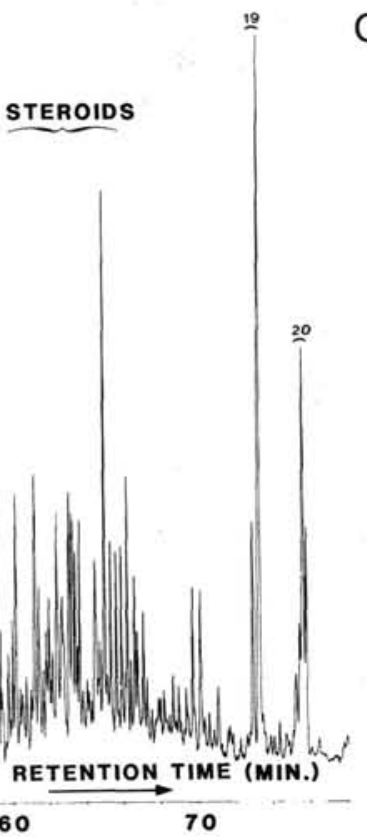

Hole 658A

183.0 MBSF

"TOTAL LIPIDS"
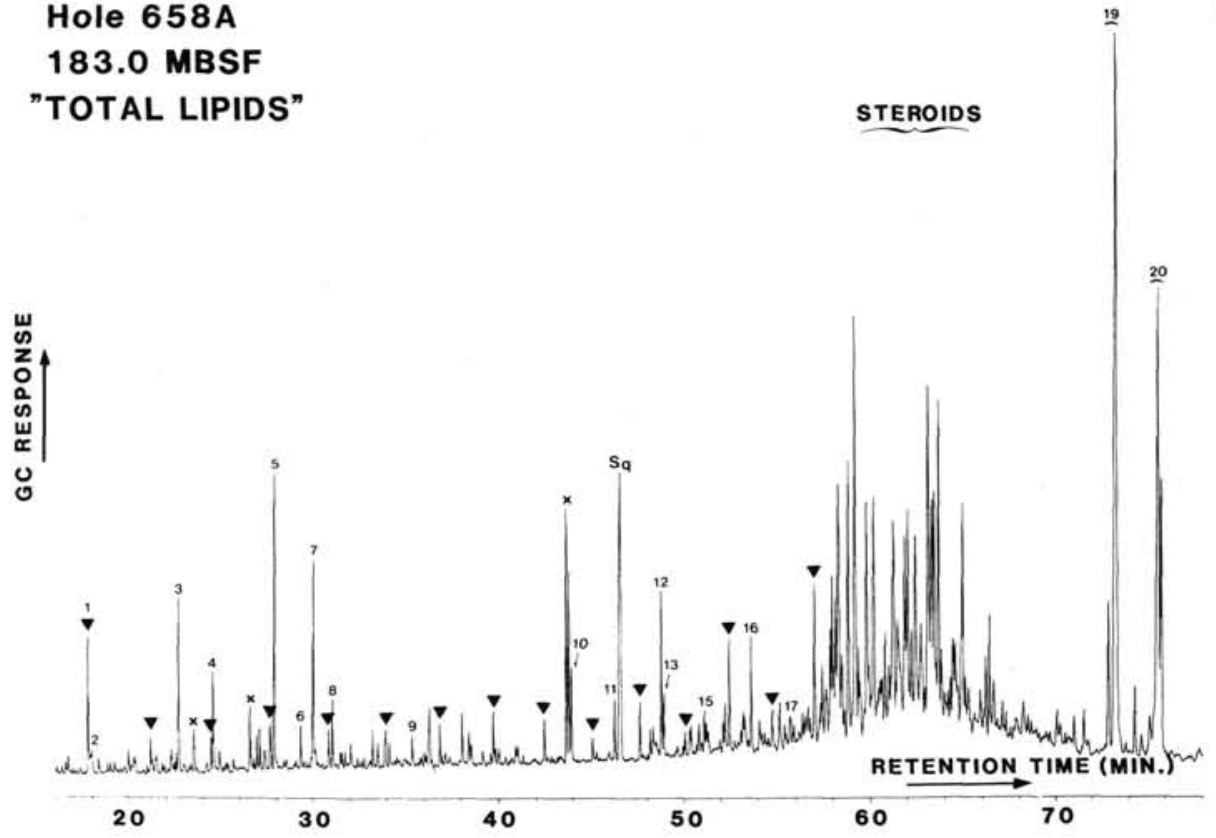

Figure 5 (continued).

\section{CONCLUSIONS}

The lipid composition in the organic solvent extracts of sediments from Site 658 provides supporting evidence for the existence of coastal upwelling off northwest Africa during Pliocene to Pleistocene times. Increased primary productivity, high sedimentation rates, and oxygen-depleted water masses associated with upwelling may have supported preservation of the biomass of decayed marine organisms. Abundant steroids, long-chain unsaturated ketones, and other molecular indicators show that preservation was good to excellent throughout the time span studied. The variations in total organic-carbon contents may be related either to dilution with inorganic sediment components or to variations in the primary productivity over geological time or to a combination of both.
In accordance with organic petrographic results and pyrolysis yields (Stein et al., this volume), terrigenous organic matter is generally of secondary importance in the continental slope sediments at Site 658 . This conclusion can only be derived when the total lipid fraction is considered. Inspection of the aliphatic hydrocarbon fractions alone leads to an overestimation of the terrigenous influence because in this fraction the higher land-plant wax alkanes strongly dominate. This is because land-plant hydrocarbons are directly introduced into the sediments as biogenic compounds in relatively high abundance. The lipids of marine organisms, on the other hand, must undergo extensive diagenesis before they are converted into hydrocarbons, thus minimizing their relative importance as a fraction of the total organic matter. Bacterial lipids are apparently of intermediate importance. 


\section{Hole 658A}

276.3 MBSF

"TOTAL LIPIDS"
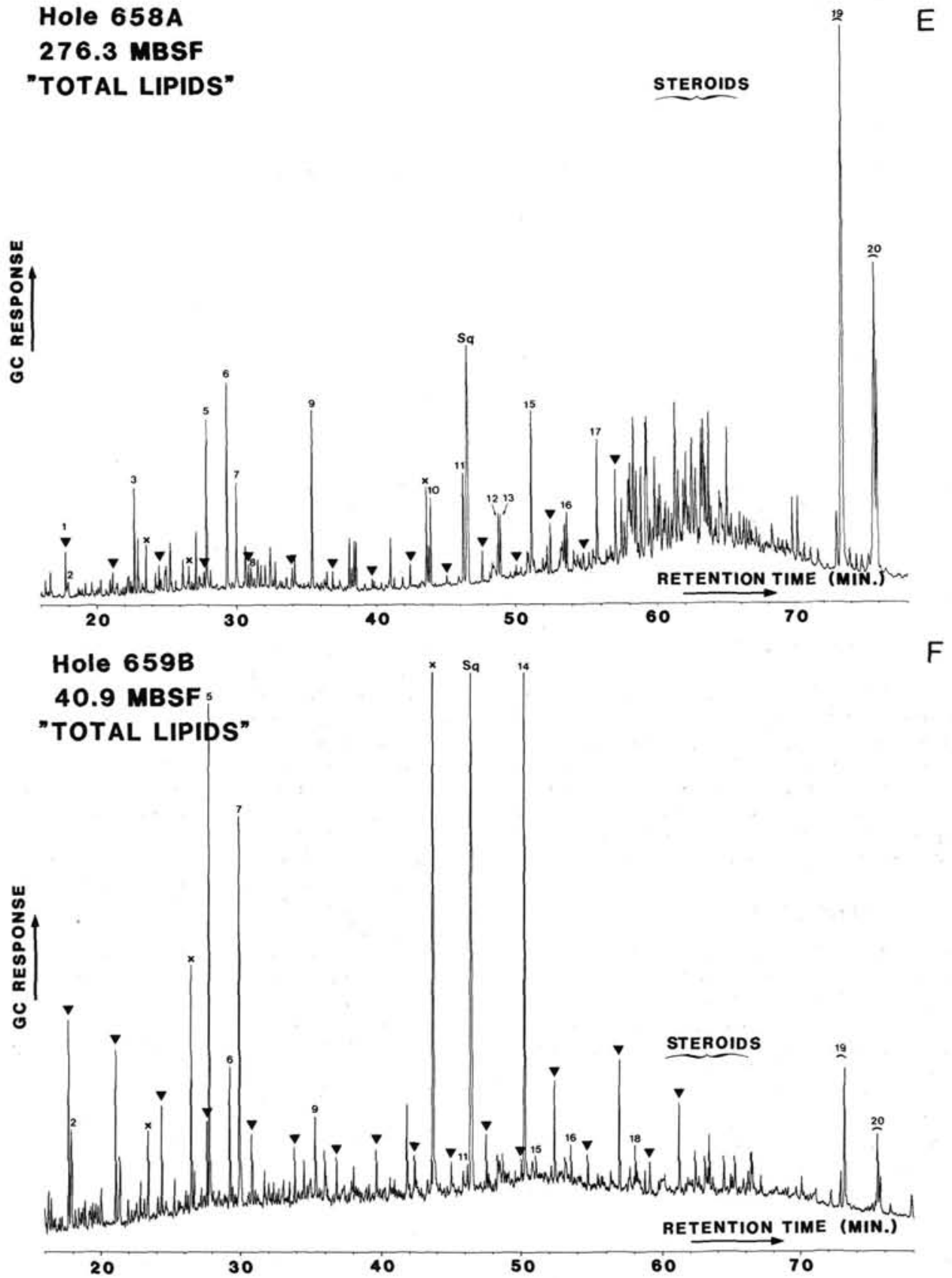

Figure 5 (continued).

The sediments on the Cape Verde Plateau farther to the southwest (Site 659), where no upwelling is observed at present, obviously were also not influenced by upwelling in the geological past. Thus, surface-water productivity may have been distinctly lower at Site 659 than at Site 658. This has resulted in a low organic-carbon content. Furthermore, the lipid composition indicates that the environmental conditions of deposition in this case favor the preservation of the more resistant lipids of terrigenous origin (particularly $n$-alkanes).

Apart from the general differences observed between Sites 658 and 659 , no direct molecular evidence was found as a specific marker for coastal upwelling. This is consistent with previous investigations (e.g., Brassell and Eglinton,
1983), but it does not exclude the possibility that such indicators do exist. The possibility also exists that a combination of molecular indicators may be recognized as an upwelling marker.

Of particular interest is the mode of occurrence of alkan2 -ones in the Site 658 sediment samples. The molecular distribution, including the strong odd-to-even carbon number predominance, and their occurrence only in the deeper sediments strongly suggest that the alkan-2-ones may be diagenetic transformation products of $\beta$-hydroxy fatty acids. These fatty acids are initially tightly bound (as amides?; Goossens et al., 1986) within the biological matrix and only later are liberated from the kerogen during diagenesis when they are subjected to further transformation. 
Table 3. Compounds identified by gas chromatography/mass spectrometry in the "total lipid"' fraction of samples from Sites 658 and 658 (Fig. 5A-F).

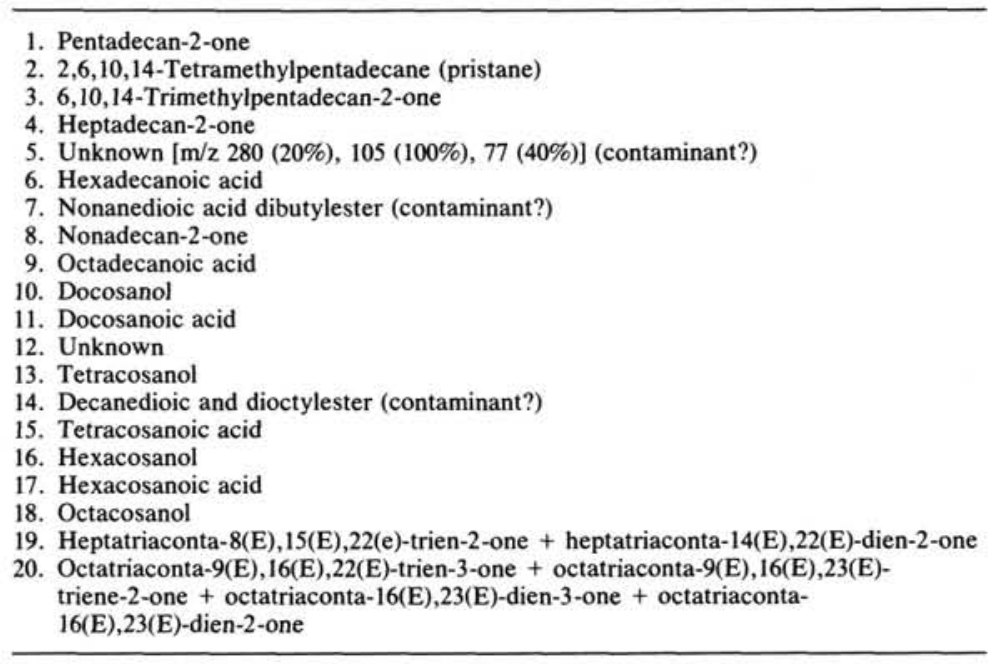

Note: Fatty acids and alcohols have been measured as trimethylsilylester derivatives.

\section{ACKNOWLEDGMENTS}

We thank the Ocean Drilling Program for providing the unique study material. The support of Professor D. H. Welte is gratefully acknowledged. We would like to thank Dr. R. Littke for kerogen microscopy, Dr. M. Radke and Dr. R. G. Schaefer for providing extraction/liquid chromatography and gas chromatography facilities, respectively, and the technical staff members for analytical support. Financial support was provided by the Deutsche Forschungsgemeinschaft (Bonn), grant no. We 346/27 and grant no. Ste 412/1.

\section{REFERENCES}

Boon, J. J., Rijpstra, W.I.C., de Lange, F., de Leeuw, J. W., Yoshioka, M., and Shimizu, Y., 1979. Black Sea sterol-a molecular fossil for dinoflagellate blooms. Nature, 277:125-127.

Brassell, S. C., 1984. Aliphatic hydrocarbons of a Cretaceous black shale and its adjacent green claystone from the southern Angola Basin, Deep Sea Drilling Project Leg 75. In Hay, W. W., Sibuet, J. C., et al., Init. Repts. DSDP, 75, Pt. 2: Washington (U.S. Govt. Printing Office), 1019-1030.

1985. Molecular changes in sediment lipids as indicators of systematic early diagenesis. In Eglinton, G., Curtis, C. D., Mckenzie, D. P., and Murchinson, D. G. (Eds.), Geochemistry of Buried Sediments. Philos. Trans. R. Soc. London, Ser. A, 315:57-73.

Brassell, S. C., Comet, P. A., Eglinton, G., Isaacson, P. J., McEvoy, J., Maxwell, J. R., Thomson, I. D., Tibbets, P.J.C., and Volkman, J. K., 1980. The origin and fate of lipids in the Japan Trench. In Douglas, A. G., and Maxwell, J. R. (Eds.), Advances in Organic Geochemistry, 1979: Oxford (Pergamon Press), 375-392.

Brassell, S. C., and Eglinton, G., 1983. The potential of organic geochemical compounds as sedimentary indicators of upwelling. In Suess, E., and Thiede, J. (Eds.), Coastal Upwelling: Its Sedimentary Record (Pt. A): New York (Plenum Press), 545-571.

Brassell, S. C., Eglinton, G., Marlowe, I. T., Pflaumann, U., and Sarnthein, M., 1986. Molecular stratigraphy: a new tool for climatic assessment. Nature, 320:129-133.

Brassell, S. C., Wardroper, A.M.K., Thomson, I. D., Maxwell, J. R., and Eglinton, G., 1981. Specific acyclic isoprenoids as biological markers of methanogenic bacteria in marine sediments. Nature, 290:693-696.

Cranwell, P. A., 1977. Organic geochemistry of Cam Loch (Sutherland) sediments. Chem. Geol., 20:205-221.

de Leeuw, J. W., Rijpstra, W. I. C, Schenck, P. A., and Volkman, J. K., 1983. Free, esterified and residual bound sterols in Black Sea Unit I sediments. Geochim. Cosmochim. Acta, 47:455-465.
Eglinton, G., and Hamilton, R. J., 1963. The distribution of alkanes. In Swain, T. (Ed.), Chemical Plant Taxonomy: London (Academic Press), 187-208.

Goossens, H., Rijpstra, W.I.C., Düren, R. R., de Leeuw, J. W., and Schenck, P. A., 1986. Bacterial contribution of sedimentary organic matter: a comparative study of lipid moieties in bacteria and recent sediments. In Leythaeuser, D., and Rullkötter, J. (Eds.), Advances in Organic Geochemistry, 1985: Oxford (Pergamon Press), 683-696.

Ikan, R., Baedecker, M. J., and Kaplan, I. R., 1973. C 18 -isoprenoid ketone in recent marine sediment. Nature, 244:154-155.

Klok, J., Baas, M., Cox, H. C., de Leeuw, J. W., and Schenck, P. A., 1984. Loliolides and dihydroactinidiolide in a recent marine sediment probably indicate a major transformation pathway of carotenoids. Tetrahedron Lett., 25:5577-5580.

Leg 108 Shipboard Scientific Party, 1986. Palaeoclimatic linkage between high and low latitudes. Nature, 322:211-212.

Marlowe, I. T., Brassell, S. C., Eglinton, G., and Green, J. C., 1984. Long-chain unsaturated ketones and esters in living algae and marine sediments. In Schenck, P. A., de Leeuw, J. W., and Lijmbach, G.W.M. (Eds.), Advances in Organic Geochemistry, 1983: Oxford (Pergamon Press), 135-141.

McEvoy, J., Eglinton, G., and Maxwell, J. R., 1981. Preliminary lipid analyses of sediments from sections $467-3-3$ and 467-97-2. In Yeats, R. S., Haq, B. U., et al., Init. Repts. DSDP, 63: Washington (U.S. Govt. Printing Office), 763-774.

Morrison, R. I., 1969. Soil lipids. In Eglinton, G., and Murphy, M.T.J. (Eds.), Organic Geochemistry: Methods and Results: Berlin-Heidelberg-New York (Springer-Verlag), 558-575.

Ourisson, G., Albrecht, P., and Rohmer, M., 1984. The microbial origin of fossil fuels. Sci. Am., 251:34-41.

Radke, M., Sittardt, H. G., and Welte, D. H., 1978. Removal of soluble organic matter from rock samples with a flow-through extraction cell. Anal. Chem., 50:663-665.

Radke, M., Willsch, H., and Welte, D. H., 1980. Preparative hydrocarbon group type determination by automated medium pressure liquid chromatography. Anal. Chem., 52:406-411.

Repeta, D. J., and Gagosian, R. B., 1987. Carotenoid diagenesis in recent marine sediments: I. The Peru continental shelf $\left(15^{\circ} \mathrm{S}\right.$, $\left.75^{\circ} \mathrm{W}\right)$. Geochim. Cosmochim. Acta, 51:1001-1009.

Robinson, N., Eglinton, G., Brassell, S. C., and Cranwell, P. A., 1984. Dinoflagellate origin for sedimentary $4 \alpha$-methyl steroids and $5 \alpha(\mathrm{H})$-stanols. Nature, $308: 439-441$.

Simoneit, B.R.T., 1978a. The organic geochemistry of marine sediments. In Riley, J. P., and Chester, R. (Eds.), Chemical Oceanography (Vol. 7): New York (Academic Press), 233-311. 


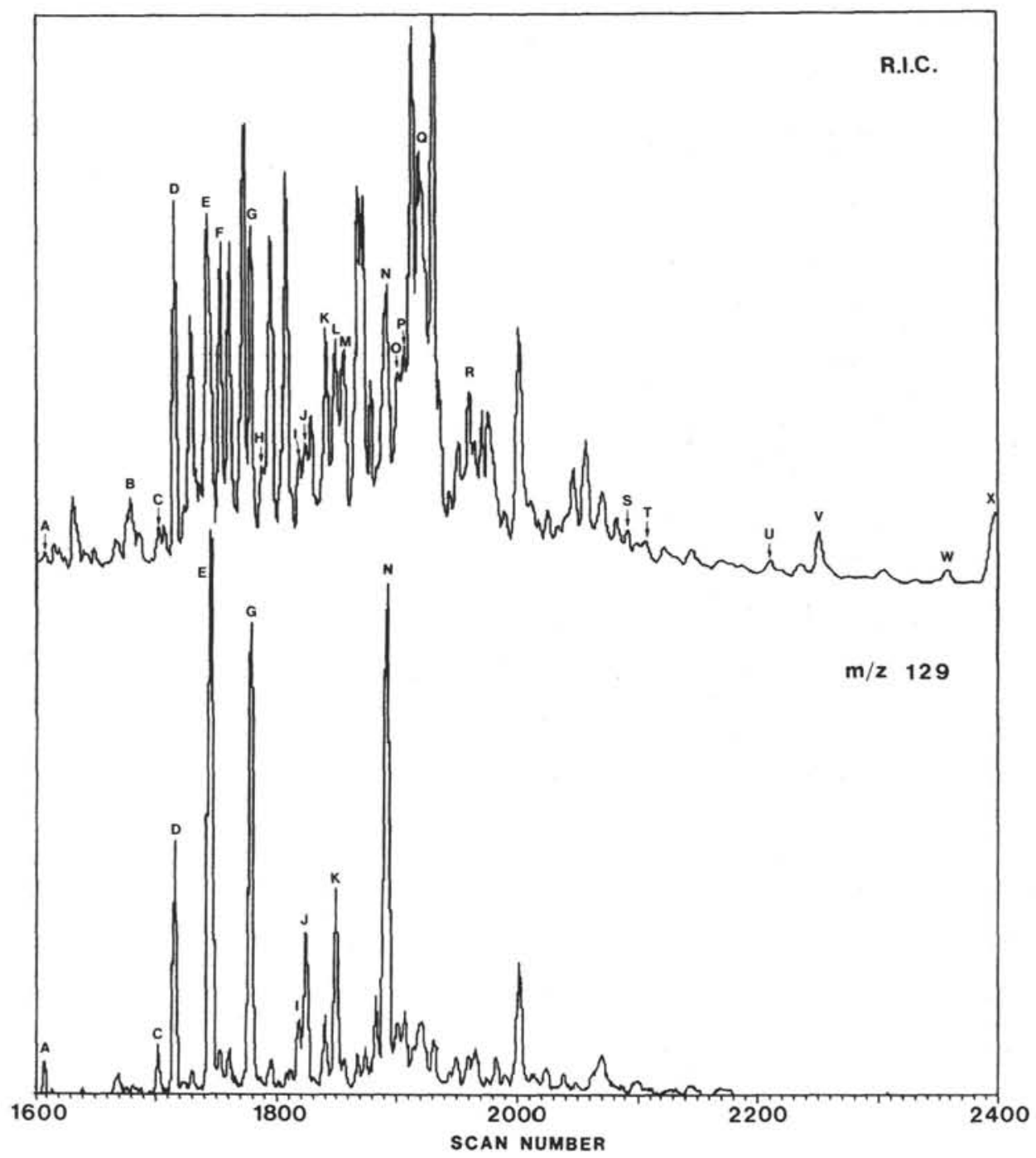

Figure 6. Partially reconstructed ion chromatogram (RIC) and $\mathrm{m} / \mathrm{z} 129$ mass chromatogram of steroid/hopanoid elution range of Sample 108-658A-21X-6, 7-14 cm. Identification of the lettered compounds is given in Table 4.

1978b. Organic geochemistry of terrigenous muds and various shales from the Black Sea, DSDP Leg 42B. In Ross, D. A., Neprochnov, Y. P., et al., Init. Repts. DSDP, 42, Pt. 2: Washington (U.S. Govt. Printing Office), 745-753.

Stein, R., Rullkötter, J., and Welte, D. H., 1986. Accumulation of organic-carbon-rich sediments in the Late Jurassic and Cretaceous Atlantic ocean-a synthesis. Chem. Geol., 56:1-32.

ten Haven, H. L., Baas, M., de Leeuw, J. W., and Schenck, P. A., 1987a. Late Quaternary Mediterranean sapropels: I. On the origin of organic matter in sapropel $\mathrm{S}_{7}$. Mar. Geol., 75:137-156.

ten Haven, H. L., Baas, M., de Leeuw, P. A., Schenck, P. A., and Brinkhuis, H., 1987b. Late Quaternary Mediterranean sapropels: II. Organic geochemistry and palynology of $\mathrm{S}_{1}$ sapropels and associated sediments. Chem. Geol., 64:149-167.

ten Haven, H. L., Baas, M., Kroot, M., de Leeuw, J. W., Schenck, P. A., and Ebbing, J., 1987c. Late Quaternary Mediterranean sapropels: III. Assessment of source of input and palaeotemperature as derived from biological markers. Geochim. Cosmochim. Acta, 51:803-810.
Volkman, J. K., 1986. A review of sterol markers for marine and terrigenous organic matter. Org. Geochem., 9:83-99.

Volkman, J. K., Eglinton, G., Corner, E.D.S., and Sargent, J. R., 1980. Novel unsaturated straight chain $\mathrm{C}_{3}-\mathrm{C}_{39}$ methyl and ethylketones in marine sediments and a coccolithophore Emiliania huxleyi. In Douglas, A. G., and Maxwell, J. R. (Eds.), Advances in Organic Geochemistry, 1979: Oxford (Pergamon Press), 219-228.

Volkman, J. K., Allen, D. I., Stevenson, P. L., and Burton, M. R., 1986. Bacterial and algal hydrocarbons in sediments from a saline Antarctic lake, Ace Lake. In Leythaeuser, D., and Rullkötter, J. (Eds.), Advances in Organic Geochemistry, 1985: Oxford (Pergamon Press), 671-681.

Date of initial receipt: 4 April 1988

Date of acceptance: 16 December 1988

Ms 108B-142 
H. L. TEN HAVEN, J. RULLKÖTTER, R. STEIN

Table 4. Compounds identified in the "total lipid" fraction (steroid/hopanoid elution range) of Sample 108-658A-21X-6, 7-14 cm (Fig. 6).

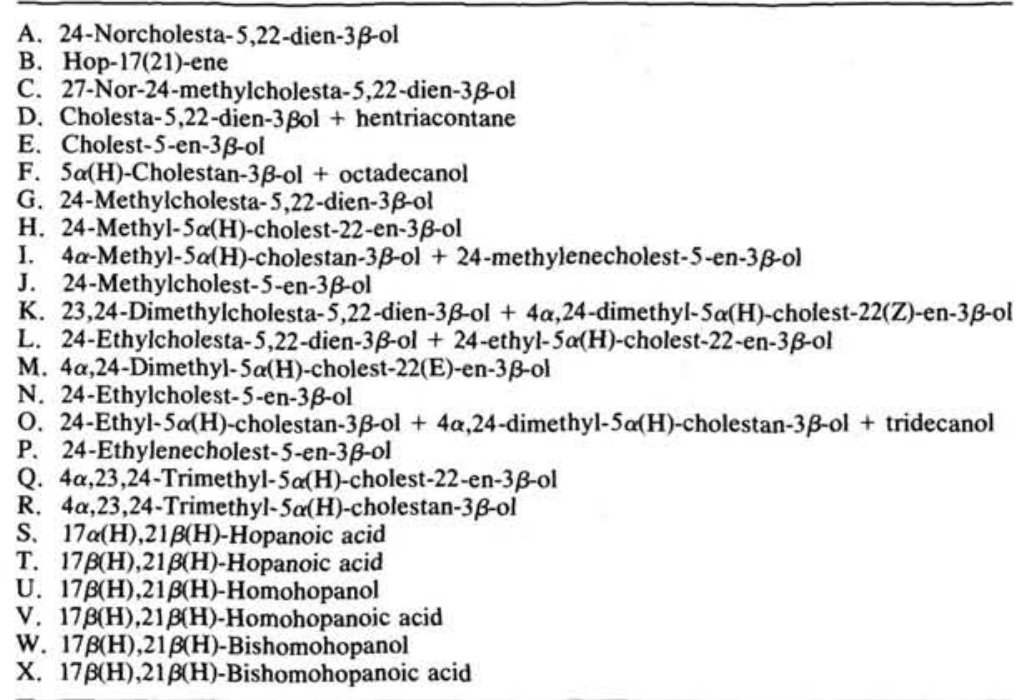

Note: Steroid and straight-chain alcohols have been measured as trimethylsilyl ethers, and hopanoic acids as methyl esters.

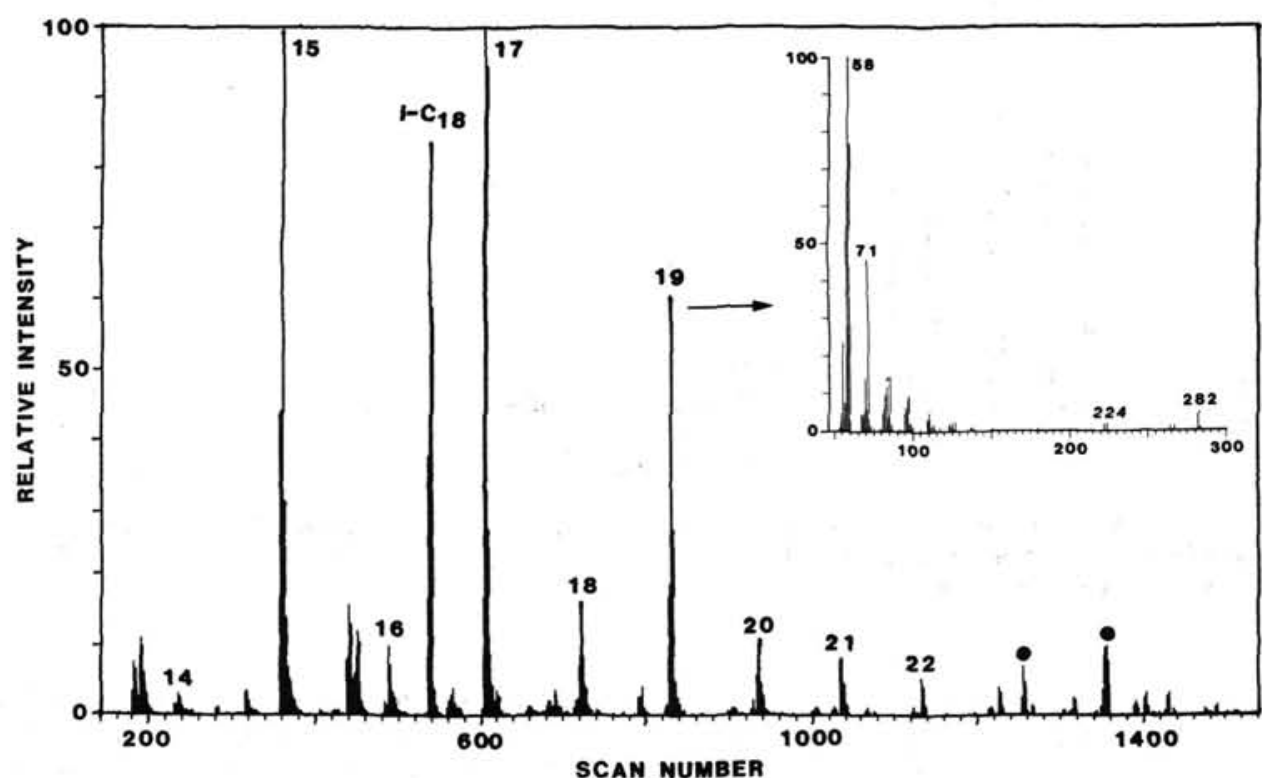

Figure 7. Partial mass chromatogram of $\mathrm{m} / \mathrm{z} 58$ showing the distribution of alkan-2-ones in Sample 108-658-21X-6, 7-14 cm, labeled by their carbon number. The isoprenoid ketone, 6,10,14-trimethylpentadecan-2-one, is indicated as $i$ - $\mathrm{C}_{18}$. The inset shows the mass spectrum of nonadecan-2-one. Dots indicate weak contributions of a phthalate ester and squalane to the $\mathrm{m} / \mathrm{z} 58$ mass chromatogram. 